\title{
Co-creation of Scratch narratives illustrated and animated by children from 4 to 6 years old
}

Ana Patrícia Oliveira apoliveira@ua.pt Maria Conceição Lopes col@ua.pt DeCA - University of Aveiro, Portugal

Reference

Oliveira, Ana Patrícia; Lopes, Maria Conceição; (2012) "Co-creation of Scratch narratives illustrated and animated by children from 4 to 6 years old", p. 347-351. In: Barbosa, Helena; Quental, Joana [Eds]. Proceedings of the 2nd International Conference of Art, Illustration and Visual Culture in Infant and Primary Education. São Paulo: Blucher, 2015. ISSN 2318-695X, ISBN: 978-989-98185-0-7

DOI 10.5151/edupro-aivcipe-66

The "Childhood with Scratch in motion" project is developed with kindergarten children and aims to show how Scratch from MIT Media Lab (an application and visual programming language for children) can promote spontaneous social playing (SSP) of children with the mediated intervention of parents and teachers. The promotion methodology is composed of several sequential stages, in which children can play and create with Scratch. This communication aims to present the children's projects created in Scratch, connecting them to the stages of the SSP promotion. These projects are multimedia animations that integrate scenarios, characters, accessories and objects, which are drawing by children or imported from the Scratch illustrations library.

\section{Introduction}

In the scope of "Childhood with Scratch in motion" project was carried out interventiontraining-experiencing sessions with Scratch programming, which take place at the Kindergarten of "Cooperativa A Torre" in Lisbon and consist of two phases, the first was conducted with children from 5 to 6 years old (2010/2011) and the second one was accomplished with children from 4 to 5 years old (2011/2012).

In 2009, it was also created a set of eleven tutorials in Scratch that are available at http://kids. sapo.pt/scratch/formacao, and characters ("Scratch in motion" guardians) that guide children in the tutorials narratives and during tutorials tasks. These contents helped children in the Scratch intervention-training-experiencing sessions.

In stage five (Exploratory playing supported by adults) of SSP methodology, children illustrated and animated new Scratch projects. These projects are based on educational contents learned by children and are inspired by the tutorials and characters from "Scratch in motion".

The SSP is a ludicity manifestation and a conceptualization that involves an iterative methodology with several steps, where the active role of adults is crucial in order to promote the autonomy and social interaction of children (Lopes, 2002). Initially children are conditioned by this dynamic so that they can explore and apprehend the opportunities offered by adults, but gradually they are released from the dependence on adults and they co-create their own projects.

Thus, the SSP emerges as the communication and experience strategy that strengthens the autonomy and cooperation among children, and among children and adults. 
$2^{\text {nd }}$ International Conference Art. Illustration and Visual Culture in Infant and Primary Education $2^{\circ}$ Congreso Internacional

Arte, Ilustración y Cultura Visual en Educación Infantil y Primaria
Congresso Internaciona

de Arte, Illustração e Cultura Visual

na Educação Infantil e Primária

\section{An approach to the concepts of illustration and animation}

\section{Scratch application and programming}

Figure 1. Programming environment of Scratch application (5th May, 2012), Source: personal.
Illustration has as main purpose to communicate an idea or concept and, generally, facilitates the understanding of a text through non-verbal language, having a pedagogical nature (Silva, 2010). Thus, illustration intends to communicate a message in a clearly and distinctive way, so it is closely linked to language, literature and storytelling, presenting itself as a type of visual paraphrase.

The well known illustrator Isidro Ferrer (2004) argues that illustration follows and clarifies always something, since it allows various interpretations of what is illustrated and not merely repeats a text, recovering its subjective nature.

Eduardo Filipe and Ju Godinho (2003) demonstrate the childish nature that are often associated to the illustrations, since they can tell stories that transport us to memories and past feelings as well as to an imaginary world of stories which accompanied us in childhood and helped us to grow. Therefore, illustration is a vehicle for the inclusion of children who do not know how to read, because they interpret the images that complement the story and can partially understand what is told. Thus, illustration made for children has its own language that aims to stimulate children's imagination through the images they see.

The process in which children learn to observe and analyze the images, creating an aesthetic consciousness is called, according to Martin Salisbury (2007), visual literacy, since children make use of their previous experiences to decode and interpret the representations of the reality that are contained in images.

Animation is the action of create the motion perception in what is static (inanimate). The action of animate creates the illusion of life from static images (Wells, 1998). Typically, a basic animation is easy to create, it is only necessary to draw up a set of images that varying in form, position and details. When they are displayed in a quick sequence, their differences are not detected by the human eye and creates the sensation of movement. The animation quality increases and its movement is smoother if the images that integrate it are numerous and very detailed.

Today, with the introduction of computers, animation is influenced by digital manipulation. In computer animation the image is displayed on the computer screen and then is quickly replaced by a new image, similar to the previous one but slightly modified, with a display speed that is measured in frames per second.

Scratch application and programming (Figure 1) is based on languages like Logo and Squeak and it allows children to create and share interactive stories, games, music and animations.
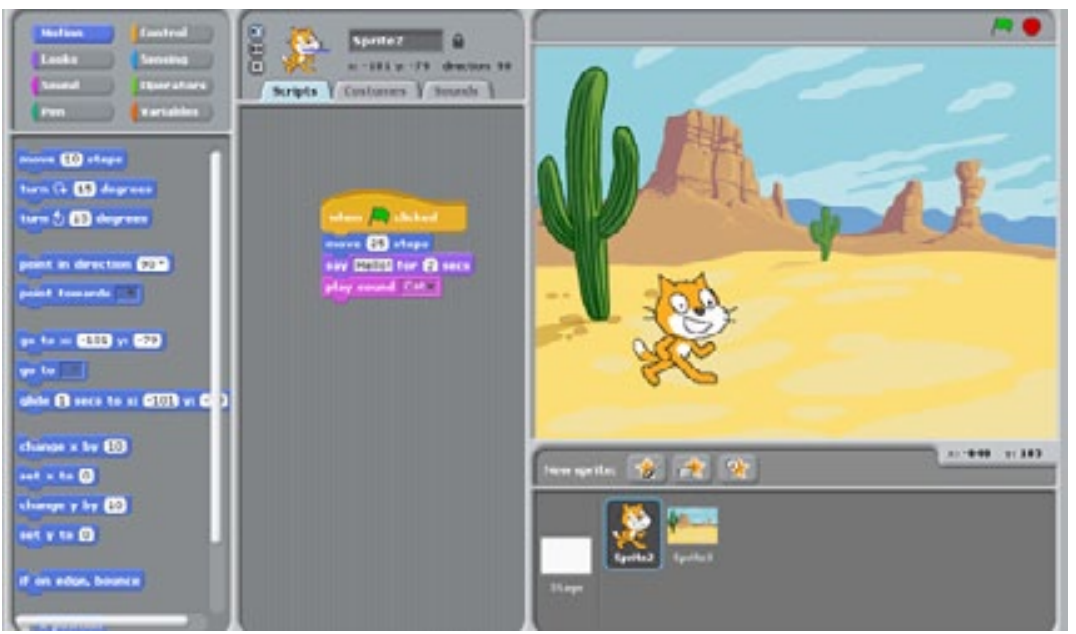
$2^{\text {nd }}$ International Conference Art, Illustration and Visual Culture in Infant and Primary Education $2^{\circ}$ Congreso Internaciona

Arte, llustración y Cultura Visual en Educación Infantil y Primaria
${ }^{\circ}$ Congresso Internacional

de Arte, Ilustração e Cultura Visual

na Educação Infantil e Primária

Children, through the simple programming tools available in Scratch, have the possibility to practice their logical thinking and explore their creativity, while these skills are applied on development of projects. These projects can be created offline through Scratch application and shared online on the community site, where children can clarify doubts and learn more with other users.

The core design principles of Scratch are essentially three: make Scratch more intuitive, more meaningful and more social compared to other programming environments (Monroy-Hernández and Resnick, 2008).

Rusk et al. (2003) advocates that new generation develops 21st century learning skills with the Scratch use, such as information and communication abilities, thinking and problem-solving skills, and interpersonal and collaboration competences. Thus, Scratch programming is a privilege medium for promoting different capacities of children and youth in a pleasurable and interactive way.

The creation of a Scratch project requires that children conceptualize an idea and decompose a problem into smaller actions in order to aggregate the programming blocks. While children create the block structure, they can also dynamically change code segments in real time and view the results of their actions. In this process of conceptualization and design, children experience, identify, formulate and solve problems interactively.

Since Scratch is an open programming environment, the community can change and contribute to projects of other users, so young people must be able to take responsibility for what they create and adapt themselves according to the reaction of other users.

\section{Spontaneous social playing methodology}

The iterative process of SSP promotion using Scratch programming consists of eight stages which allow understanding on what level children are when they play with Scratch. This level is qualified by the playing type, the interaction nature and the participation type of children. The stages are explained below.

Stage zero - Creation of the inter-institutional cooperation: At this stage the partnerships were established, there was the definition of protocols for the intervention, training and research and the intervention and evaluation methodologies were determined.

Stage one - Approach to Scratch: 1st phase - In the first phase was established the interpersonal communication with the participants. In relation to the intervention with children, this was the moment when stories of "Pópio" and "Pópia" were told. These characters are the young guardians of "Scratch in motion". 2nd phase - There was the approach to Scratch programming with the introduction to the main application functions and the presentation of its menu bar.

Stage two - Tutored circumscription (Scratch exploration phase with the guidance of adults, using 'Pópio and Pópia' tutorials): 1st phase - In this phase were used the 'Pópio and Pópia' tutorials to present and explain the key concepts related to Scratch. 2nd phase - It was made the import of Pópio and Pópia characters. Children also practiced the zooming function on images. 3rd phase - There was the consolidation of learned concepts and other concepts and blocks were introduced, such as, 'to play a sound' and 'change a frame of a character'.

Stage three - Friendship (advanced training phase in Scratch, using 'A day on the Farm' tutorial): 1st phase - It was presented and explained the story animation of the Pópio and Pópia guardians with friends on the farm. 2nd phase - In this phase were used more complex concepts related to Scratch programming: the blocks 'wait some seconds' and 'go to $\mathrm{x}$ and $\mathrm{y}$ position'

Stage four - Advised recreation (adults support to children's requests): 1st phase - Children recreated 'Pópio and Pópia' and 'A day on the Farm' tutorials and adults advised them, answering their questions and doubts while children were playing in Scratch.

Stage five - Exploratory playing supported by adults: 1st phase - After the advised recreation of tutorials, children created with adults new projects in Scratch. The programming language 
$2^{\text {nd }}$ International Conference Art, Illustration and Visual Culture in Infant and Primary Education $2^{\circ}$ Congreso Internacional

Arte, Ilustración y Cultura Visual en Educación Infantil y Primaria gresso Internacional

de Arte, llustração e Cultura Visual

na Educação Infantil e Primária

\section{Scratch narratives created by children}

Figure 2 and 4 . On the left: Scratch illustration of the poems "Lianor" by Luís de Camões and "A Porta" by Vinicius de Moraes, Mafalda (aged 5) and Inês (aged 5), (2nd June 2010). Kindergarten of "Cooperativa a Torre", Lisboa, Portugal. Source: personal. On the right: Scratch illustration of a part from the book "The Secret of the River" by Miguel Sousa Tavares, Manuel (aged 4) and Rodrigo (aged 5), (31th March, 2011). Kindergarten of "Cooperativa a Torre", Lisboa, Portugal. Source: personal. supported the educational process and children were challenged to use Scratch as a tool for building projects.

Stage six - Spontaneous social playing with Scratch: 1st phase - Children had the opportunity to play in Scratch without the intervention of adults, who were only present to help children in occasional problems with the application and hardware.

Stage seven - Sharing and disclosure of projects: 1st phase - Children's projects, which emerged from the connection between educational practices and Scratch programming, were presented to parents, teachers and school community through an exhibition.

Stage eight - Dramatic social playing with Scratch: 1st phase - In the final stage of the methodology children create their own Scratch projects and stories scripts with autonomy.

As mention before, in stage five of SSP methodology, children had the possibility to play in Scratch while they were creating new narratives, which were illustrated and animated by them.

In the first phase of the research, the children with 5-6 years old have created a short narrative that illustrates the poetry from Brazilian and Portuguese authors discovered and learned by them in the classroom context. In general, children used the characters/guardians Pópia and Pópio to represent human figures described in the poems and they have drawn objects and accessories, which were also mentioned in the poems, with strong colours and consistent lines, sometimes filling them with textures. After creating the graphics composition, children animate the illustration using simple programming commands.

On the other hand, in the second phase, the children with 4-5 years old had a different inspiration for the creation of new Scratch projects. In this case, the educational resource was the story of the book "The Secret of the River" by Miguel Sousa Tavares. The story was divided into twelve parts, which were selected by twelve pairs of children who illustrated and animated them in Scratch. As each animation is part of the same story, it was used a single drawing for each character, for this there was a contest between children drawings in order to choose the best characters. In terms of design, the selected characters are brightly coloured, predominantly with warm colours and are filled with solid colours or textures. The scenarios are photographs of a scale model of the village where the story of the book takes place. This composition of different types of graphics does not produce visual noise, in fact all elements are integrated as a whole. The animations made by children incorporate simple commands essentially of motion and appearance.

The Figure 2 represents simultaneously two poems, one is about Lianor, a girl that lives in the country and walks with a pot of water on the head. The child chose Pópia to represent Lianor and selected Pópio to walk with her, and also drew Lianor's pot of water. The other poem is titled "A porta" - The door, and speaks about a smart door that opens for the little boy, but not for ungrateful people. The little boy is Pópio and the child also drew the door with some detail.
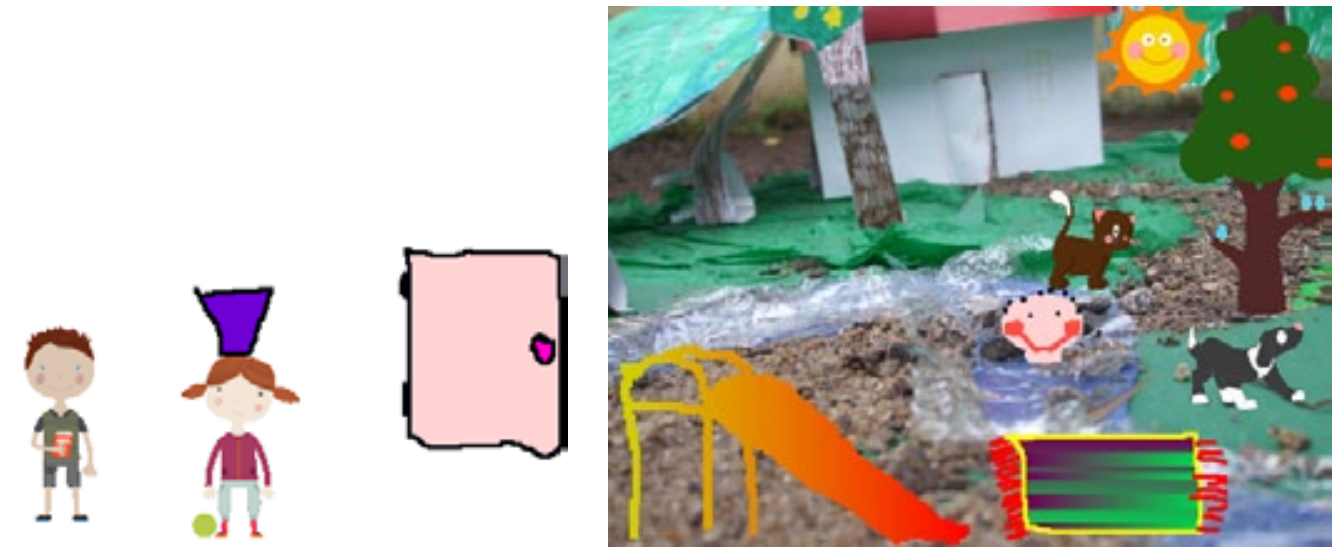
2nd International Conference Art, Illustration and Visual Culture in Infant and Primary Education

The Figure 3 illustrates a passage from the book "The Secret of the River", a story about the friendship between a boy (who lives in the country) and a fish (a carp) that lives on the river where the boy plays. In this story's part the boy swims in the river on a sunny day. In order to illustrate this, children imported some elements from "Scratch in motion" tutorials, like the sun, the cat, the dog and the tree, and drew others (the towel and the slide). The boy character was drawing by other child, because was chosen as the best character to be used in all the illustrations.

\section{Conclusion}

\section{Bibliographical references}

Escoda, E. y Bolivar, E. (2007). "Entrevista a Isidro Ferrer, ganador del Premio Nacional de Ilustración: El trabajo de un ilustrador consiste en iluminar un texto". Revista de Literatura, Especial Premios Litararios, $n^{\circ}$ 227, pp. 47-49.

Filipe, E. e Godinho, J. (2003). Ilustrarte - Bienal internacional de ilustração para a infância, 2003. Lisboa: Instituto Piaget.

Lopes, C. (2002). "A promoção do exercício social da aprendizagem dos direitos humanos". Actas do Encontro Internacional - Educação para os direitos humanos. Lisboa: Instituto de Inovação Educacional e Ministério da Educação.

Monroy-Hernández, A. and Resnick, M. (2008). "Empowering kids to create and share programmable media”. Interactions Magazine (ACM), 15, 2, pp. 50-53.

Rusk, N., Resnick, M. and Maloney, J. (2003). Learning with Scratch, 21st Century Learning Skills. Lifelong Kindergarten Group, MIT Media Laboratory.

Salisbury, Martin (2007). Imágenes que cuentam, nueva ilustración de libros infantiles. Barcelona: Editorial Gustavo Gili.

Silva, Miriam (2010). Um Livro Vivo, transposição para a web do livro para crianças 'Histórias de pretos e de brancos'. Dissertação de Mestrado em Design. Aveiro: Universidade de Aveiro.

Wells, Paul (1998). Understanding Animation. London: Routledge. 